BIOMEDICAL AND BIOSOCIAL ANTHROPOLOGY
$\begin{gathered}\text { Official Journal of the International Academy } \\ \text { of Integrative Anthropology } \\ \text { journal homepage: http://bba-journal.com }\end{gathered}$

\title{
Features of histological changes in the lungs of mature animals under conditions of hyperhomocysteinemia
}

\author{
Samborska I. A. ${ }^{1}$, Maievskyi O. Ye. ${ }^{2}$, Nebesna Z. M. ${ }^{3}$ \\ ${ }^{1}$ National Pirogov Memorial Medical University, Vinnytsya, Ukraine \\ ${ }^{2}$ Taras Shevchenko National University of Kyiv, Kyiv, Ukraine \\ IIvan Horbachevsky Ternopil National Medical University of the Ministry of Health of Ukraine, Ternopil, Ukraine
}

\section{ARTICLE INFO}

Received: 17 September, 2019

Accepted: 22 October, 2019

UDC: $616.24: 577.112 .386: 599.323 .45$

CORRESPONDING AUTHOR

e-mail: samborska1990@gmail.com Samborska I. A.
Hyperhomocysteinemia is a well-known risk factor for atherosclerosis, coronary heart disease, stroke, and venous thrombosis. However, in recent decades, the range of diseases associated with elevated homocysteine levels has expanded significantly. The influence of this amino acid on the occurrence and development of pathologies of the respiratory system, in particular, chronic obstructive pulmonary disease, bronchial asthma, lung and pleural cancer, is currently being actively studied. The aim of the study is to find the features of histological changes in the lungs of adult rats under conditions of hyperhomocysteinemia. The experimental study was performed on 22 white nonlinear adult (6-8 months) male rats. During the experiment, the animals were divided into two groups - control and experimental. Simulation of the state of persistent hyperhomocysteinemia was achieved by administering to rats the experimental group of thiolactone homocysteine at a dose of $200 \mathrm{mg} / \mathrm{kg}$ body weight intragastrally for 60 days. Histological specimens were studied using an SEO CCAN light microscope and photo-documented using a Vision CCD Camera with an image output system from histological specimens. Histological examinations of the lungs of adult animals under conditions of hyperhomocysteinemia revealed adaptive-compensatory and destructive changes in the components of the organ. Discirculatory disorders, remodeling of the bronchial wall with the formation of inflammatory infiltrates in them were revealed. Significant areas of dys- and atelectasis and emphysematically altered areas of the parenchyma were found in the respiratory tract of the lungs. In the alveolar septa, peribronchially and paravasally, histo- and leukocyte infiltration, formation of inflammatory conglomerates were determined. Remodeling of vascular walls, especially the microcirculatory tract leads to disruption of blood supply to the body and hypoperfusion of lung tissue.

Keywords: hyperhomocysteinemia, vascular remodeling, endothelial dysfunction, dyscirculatory disorders.

\section{Introduction}

Respiratory diseases today are extremely common among children and adults. The reasons for their development are polyetiological and are being actively studied. Currently, there is some evidence in the scientific literature on the involvement of endothelial dysfunction in the occurrence and progression of respiratory diseases. The latter differ in the causes and mechanisms of development, but the potential factors of endothelial damage in each of them are universal, namely: focal or diffuse inflammation of bronchopulmonary tissue, disorders of free radical oxidation, hypoxia, proteinase imbalance, neurohumoral dysfunction [2, 6, 10, 18]. The main triggers that can activate the mechanisms of endothelial damage are cytokines, bacterial toxins, pollutants of tobacco smoke, immune complexes, free radicals, and so on. These factors are well known and have a significant evidence base. However, it was found that one of the causes of respiratory pathologies is an increase in the concentration of plasma homocysteine. Under normal conditions, homocysteine plays an important role in maintaining a constant level of the essential amino acid methionine in the body. The increase in its content in the blood is accompanied by a number of negative changes in organs and systems, one of which is endothelial 
damage. The realization of this effect is carried out by apoptosis and accelerated aging of endothelial cells [8, $11,17]$. In addition, homocysteine acts as a procoagulant, inhibiting the activity of antithrombin III, heparin and increases the activity of thrombin, which ultimately creates the basis for the development of thrombosis. Available data on its effect on the formation and bioavailability of nitric oxide. Scientific studies also demonstrate the dependence of the thickness of the intima-media layer of the vascular wall on the level of blood plasma homocysteine $[3,12,15$, 22, 23].

Based on the above data, homocysteine is a powerful factor in the development of pathological conditions, but it is important to deepen the study of its effect on the structure and function of the respiratory system and to establish the relationship between increasing its level in the blood and dysfunction of bronchopulmonary and microcirculatory system.

The aim of the research is to study the features of histological changes in the lungs of adult rats under conditions of hyperhomocysteinemia.

\section{Materials and methods}

The experiments were performed on 22 white nonlinear adult (6-8 months) male rats. During the experiment, the animals were divided into two groups - control and experimental. Simulation of persistent hyperhomocysteinemia was achieved by administering to rats the experimental group of thiolactone homocysteine at a dose of $200 \mathrm{mg} / \mathrm{kg}$ body weight intragastrically for 60 days [13]. Animals were decontaminated by decapitation under thiopental anesthesia [4]. For microscopic examination, pieces of lungs were taken from pre-weighed animals of all groups. The pieces were fixed in $10 \%$ formalin solution, while the duration of exposure did not exceed 1-2 days. The applied fixing solution prevents the process of autolysis and stabilizes cells and tissues for their further processing and use in staining procedures. Next, the pieces were dehydrated in alcohols of increasing concentration and poured into paraffin blocks. The prepared sections, 4-5 ?m thick, were stained with hematoxylin and eosin and methylene blue [7]. Histological specimens were studied using an SEO CCAN light microscope and photo-documented using a Vision CCD Camera with an image output system from histological specimens.

\section{Results}

Conducted microscopic studies of the lungs of adult white rats under the conditions of simulated hyperhomocysteinemia revealed dyscirculatory disorders, remodeling of the bronchial wall with the formation of inflammatory infiltrates. Arteries of mainly large diameter are characterized by destructive changes, which are manifested by uneven thickening or thinning of the media, violation of the structural organization of the intima with signs of edema and desquamation of the endothelium into the lumen of the vessel. The inner elastic membrane is indistinctly contoured, deformed, homogeneous in some areas. The lumen is irregular, blood-filled (Fig. 1). In adventitia, there is an overgrowth of collagen and reticular fibers and bulky accumulations of leukocyte infiltrates.

Small arteries are characterized by excessive media hypertrophy and, accordingly, narrowing of the lumen as a manifestation of compensatory mechanisms of circulatory disorders in hyperhomocysteinemia. The veins have mainly dystonically altered, thin wall, blood-filled lumen, in which neutrophils, platelets, erythrocytes are found, their adventitia is significantly infiltrated. Marginal standing of lymphocytes near the endothelium was noted (Fig. 2, Fig. 3).

In vessels of small diameter and hemomicrocirculatory

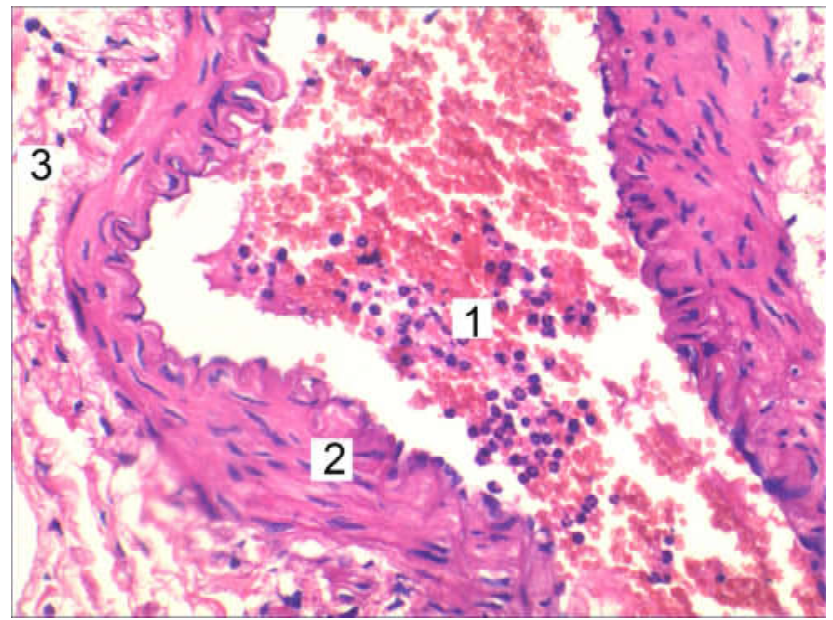

Fig. 1. Histological changes in the lungs of mature animals under conditions of hyperhomocysteinemia. Blood-filled lumen of a large diameter artery (1), media (2) and adventitia deformation (3). Staining with hematoxylin and eosin. $x 200$.

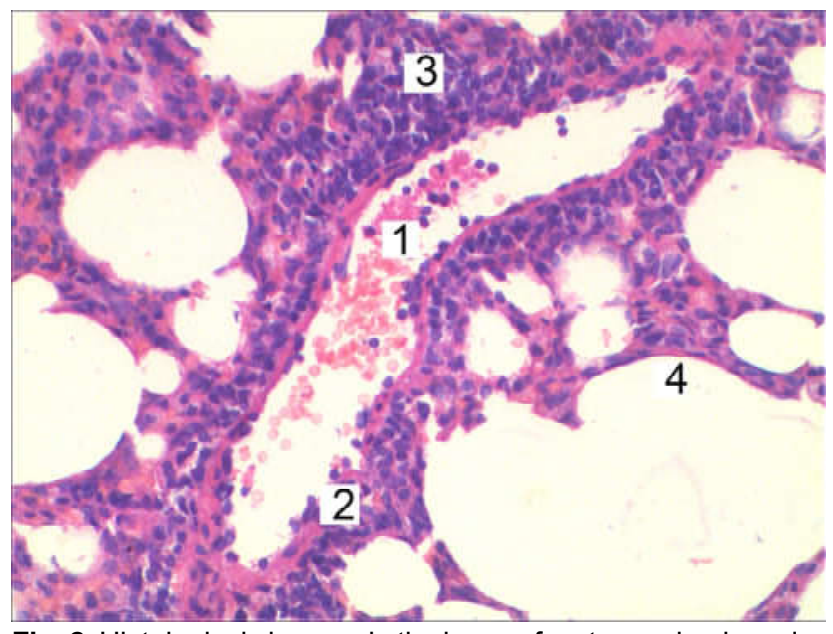

Fig. 2. Histological changes in the lungs of mature animals under conditions of hyperhomocysteinemia. Lumen of a vein of average diameter (1) with the formed elements of blood, destructively changed wall (2). Perivascular infiltration by lymphocytes (3), respiratory department (4). Staining with hematoxylin and eosin. x200. 


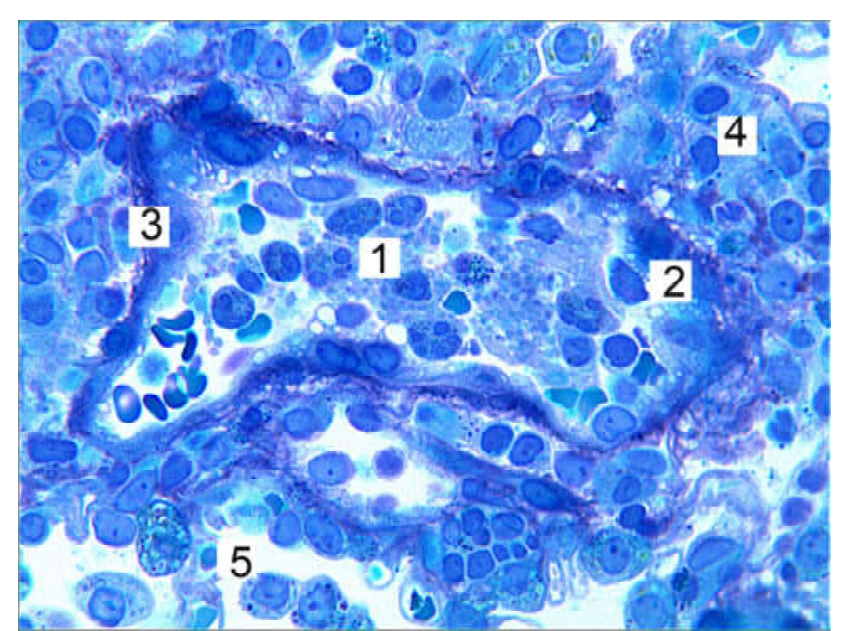

Fig. 3. Microscopic changes in the lungs of an adult animal under conditions of hyperhomocysteinemia. Blood-filled lumen of the vein of small diameter (1), edema and destruction of endothelial cells (2), fibrous structures of the media (3) infiltration of the adventitia (4), respiratory department (5). Semi-thin slice. Methylene blue staining. $\times 400$.

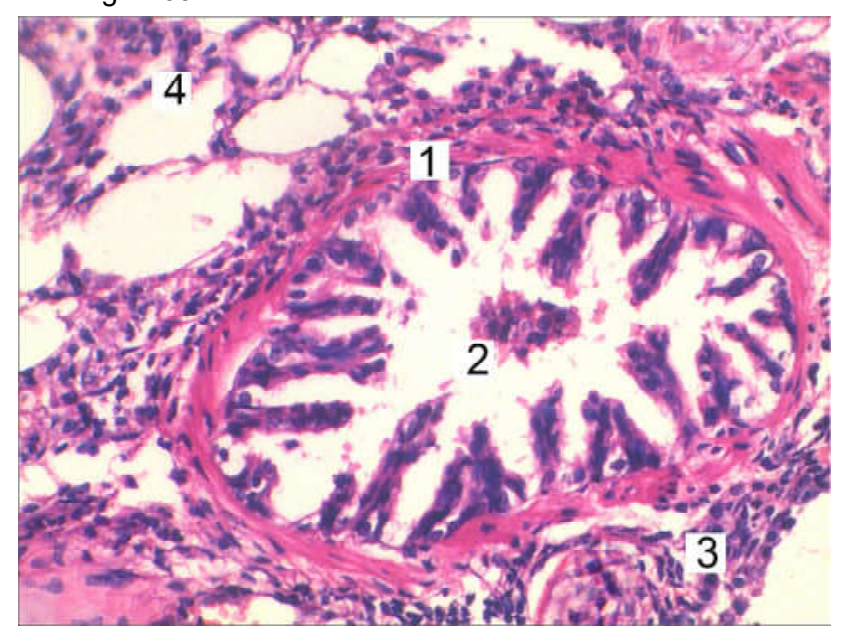

Fig. 4. Microscopic changes in the lungs of an adult animal under conditions of hyperhomocysteinemia. Destruction of the bronchial wall of medium diameter (1), desquamated respiratory epitheliocytes in the lumen (2), leukocyte-infiltrated adventitia (3), respiratory department (4). Staining with hematoxylin and eosin. x200.

tract thrombi, sludge effect of erythrocytes are observed, their wall is indistinct, blurred. There is perivascular infiltration.

Studies of bronchial reorganization have shown that most of their lumens are narrowed, spasmodic, often filled with serous-mucous contents with desquamated respiratory epithelium. There is swelling, disorganization of the fibers and the main substance of the wall, infiltration by macrophages, lymphocytes, neutrophils (Fig. 4).

In the respiratory department, quite large areas of dysand atelectasis are found. Mostly in peripheral, subpleural areas less often in the central areas of the lobes there are emphysematically altered areas, increasing infiltration of the walls of the alveoli by leukocytes, macrophages, young

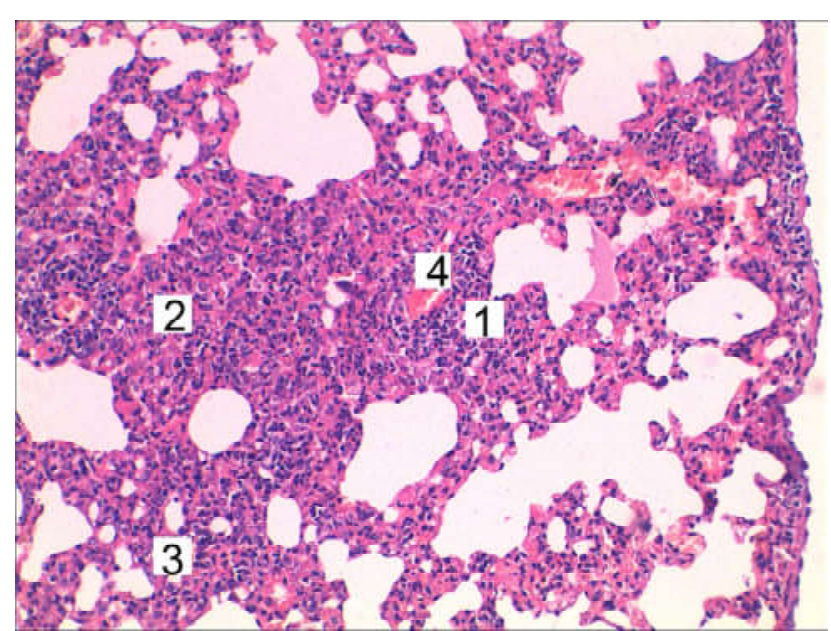

Fig. 5. Microscopic changes of the respiratory tract of a mature animal under conditions of hyperhomocysteinemia. Zones of leukocyte infiltration (1) and cell proliferation (2), areas of dysand atelectasis (3), blood-filled veins (4). Staining with hematoxylin and eosin. $\times 100$.

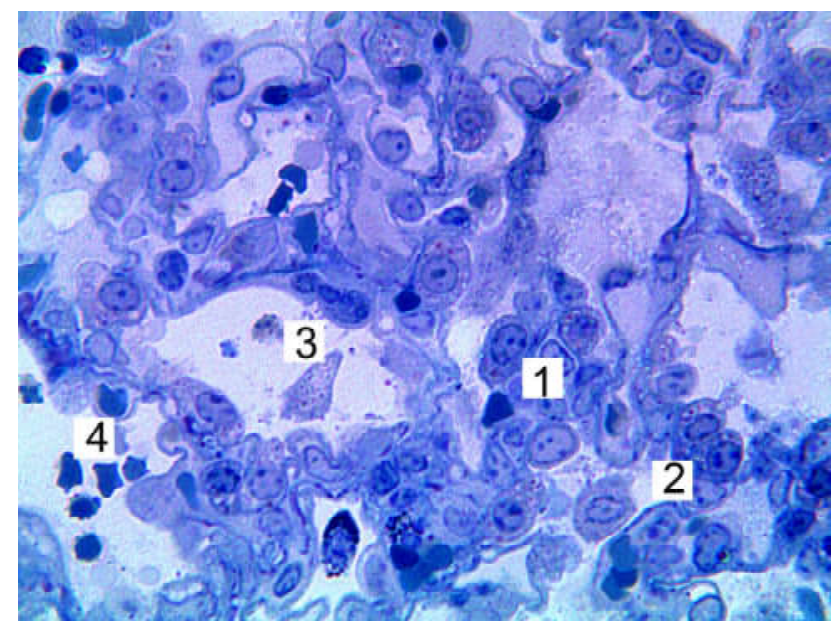

Fig. 6. Microscopic changes of the lungs of a mature animal of the respiratory department under conditions of hyperhomocysteinemia. Areas of infiltration of the alveolar wall (1), dys- and atelectasis zones (2), alveolar macrophages (3) and erythrocytes in the lumen of the alveoli (4). Semi-thin slice. Methylene blue staining. $x 400$.

and mature active fibroblasts, determined by the growth of fibrous structures in the walls of their alveoli. In the lumens of the alveoli is determined by an increase in the number of alveolar macrophages, the presence of erythrocytes due to thinning and rupture of the alveolar wall (Fig. 5, Fig. 6). Focially in the parenchyma of the organ there are small interstitial hemorrhages.

\section{Discussion}

The obtained data of histological researches agree with the results of the works available in the scientific literature.

It has been established that in most patients with chronic obstructive pulmonary disease there is an increase in plasma homocysteine levels. Scientists see the cause 
of this condition in a deficiency of vitamin B12, which causes a violation of the synthesis and utilization of homocysteine in the body. Under these conditions, there is a basis for the development of atherothrombotic complications and the risk of cardiovascular comorbidity [5].

Data from similar studies also confirm the role of homocysteine in the occurrence and progression of chronic obstructive pulmonary disease. The increase in its concentration in patients is associated with the inflammatory process and the development of oxidative stress [1].

N. A. Khan et al. [9] found that in people with chronic obstructive pulmonary disease there is a violation of folate metabolism, which is the basis for increasing the concentration of homocysteine under these conditions. The authors note that in this pathology, the amino acid has a pronounced effect on the walls of the bronchi and blood vessels, and the appointment of vitamin B9 to patients only reduces its level in the blood, but is not able to improve the functional parameters of the respiratory system.

According to some authors, the main cause of chronic obstructive pulmonary disease is long-term smoking, which causes an increase in endothelin-1 levels, damage to the epithelial lining of the bronchial wall and the development of hyperhomocysteinemia syndrome. The latter, deepening endothelial dysfunction, becomes a risk factor for cardiovascular disease [20].

It is proved that under the conditions of experimental severe hyperhomocysteinemia homocysteine does not accumulate directly in the lung tissue. However, its uneven distribution in the compartments of the cell creates the conditions for excessive intake of individual organelles,

\section{References}

[1] Abdallah, G. M., Abdullah, A., Omran, G. A., \& Mariee, A. D. (2009). Serum homocysteine level in COPD patients: possible beneficial effect of antioxidants. Res J Medicine \& Med Sci, 4(2), 306-310.

[2] Ametov, A. S., \& Kosian, A. A. (2019). The role of homocysteine in the development of diabetic polyneuropathy and endothelial dysfunction. Endocrinology: news, opinions, training, 8(1), 32-39. doi: 10.24411/2304-9529-2019-11004

[3] Arutiunian, A. V., Pustygina, A. V., Miliutina, Yu. P., Zalozniaia, I. V., \& Kozina, A. S. (2015). Molecular markers of oxidative stress in offspring with experimental hyperhomocysteinemia. Molecular medicine, (5), 41-46.

[4] Dobrelia, N. V., Boitsova, L. V. \& Danova, I. V. (2015). Legal basis for ethical examination of preclinical studies of drugs using laboratory animals. Pharmacology and drug toxicology, (2), 95-100.

[5] Fimognari, F. L., Loffredo, L., Simone, S., Sampietro, F., Pastorelli, R., Monaldo, M., ... \& D'Angelo, A. (2009). Hyperhomocysteinemia and poor vitamin B status in chronic obstructive pulmonary disease. Nutr Metab Cardiovasc Diss, 19(9), 654-659. doi: 10.1016/j.numecd.2008.12.006

[6] Hirase, T., \& Node, K. (2012). Endothelial dysfunction as a cellular mechanism for vascular failure. Am J Physiol Heart Circ Physiol, 302(3), 499-505. doi: 10.1152/ ajpheart.00325.2011 including mitochondria. The causes of this condition are not fully understood, as the mechanisms of homocysteine transport in the mitochondria are not fully understood. It is only known that on the inner membrane of the organelle there is a transporter of S-adenosylmethionine, which transfers the latter to the mitochondrial matrix, and in the opposite direction transports S-adenosylhomocysteine. Significant accumulation of homocysteine in the organelle leads to the development of oxidative stress due to nitric oxide deficiency and oxidative modification of proteins. Mitochondrial dysfunction causes cell apoptosis and lung tissue damage [14].

It is important to know the relationship between elevated plasma homocysteine levels and the development of lung and pleural cancer. According to scientists, the cause of these conditions is a violation of folate metabolism and, as a consequence, inhibition of DNA synthesis and methylation [16, 19, 21].

\section{Conclusions}

Histological examinations of the lungs of adult animals under conditions of hyperhomocysteinemia revealed adaptive-compensatory and destructive changes in the components of the organ. Remodeling of vascular walls, especially the microcirculatory tract leads to disruption of blood supply to the body and hypoperfusion of lung tissue. Significant areas of dys- and atelectasis and emphysematically altered areas of the parenchyma were found in the respiratory tract of the lungs. In the alveolar septa, peribronchially and paravasally, histo- and leukocyte infiltration, formation of inflammatory conglomerates were determined.

[7] Horalskyi, L. P., Khomych, V. T., \& Kononskyi, O. I. (2011). Fundamentals of histological technique and morphofunctional research methods in normal and pathology. Zhytomyr: Polissya.

[8] Hsu, C. C., Cheng, C. H., Hsu, C. L., Lee, W. J., Huang, S. C., \& Huang, Y. C. (2015). Role of vitamin B6 status on antioxidant defenses, glutathione and related enzyme activities in mice with homocysteine-induced oxidative stress. Food Nutr Res, (59), 25702. doi: 10.3402/fnr.v59.25702

[9] Khan, N. A., Saini, H., Mawari, G., Kumar, S., Hira, H. S., \& Daga, H. K. (2016). The effect of folic acid supplementation on hyperhomocysteinemia and pulmonary function parameters in chronic obstructive pulmonary disease: a pilot study. J Clin Diagn Res, 10(11), 17-20. doi: 10.7860/JCDR/2016/21322.8927

[10] Khrystych, T. M., Fediv, O. I., Iliushyna, A. A., Teleki, Ya. M., \& Olinyk, O. Yu. (2012). Chronic obstructive pulmonary disease: heterogeneity of course. Bukovynian Medical Bulletin, 2(62), 174-178.

[11] Lai, W. K., \& Kan, M. Y. (2015). Homocysteine-induced endothelial dysfunction. Ann Nutr Metab, 67(1), 1-12. doi: 10.1159/000437098

[12] Medvedev, D. V., \& Zviagina, V. I. (2017). Molecular mechanisms of homocysteine toxicity. Cardiology bulletin, (1), 52-57.

[13] Medvedev, D. V., Zviagina, V. I., \& Fomina, M. A. (2014). Method for modeling severe hyperhomocysteinemia in rats. Russian 
medical and biological bulletin named after academician $I$. P. Pavlov, (4), 42-46.

[14] Medvedev, D. V., Zviagina, V. I., Uriasev, O. M., Belskikh, E. S., Butoletskii, S. V., \& Riabkov, A. N. (2017). Metabolic changes in lung mitochondria during experimental hyperhomocysteinemia in rats. Biomedical chemistry, (3), 248254. doi: 10.18097/PBMC20176303248

[15] Skovierova, H., Vidomanova, E., Mahmood, S., Sopkova, J., Drgova, A., Cervenova, T., ... \& Lehotsky, J. (2016). The molecular and cellular effect of homocysteine metabolism imbalance on human health. Int J Mol Sci, 17(10), 1733. doi: 10.3390/ijms17101733

[16] Stanislawska-Sachadyn, A., Borzyszkowska, J., Krzeminski, M., Janowicz, A., Dziadziuszko, R., Jassem, J., ... \& Limon, J. (2019). Folate/homocysteine metabolism and lung cancer risk among smokers. PLoS ONE, 14(4): e0214462. doi: 10.1371/ journal.pone.0214462

[17] Stojanovic, M., Scepanovic, L., Bosnic, O., Mitrovic, D., JozanaStankov, O., Scepanpvic, V., ... \& Djuric, D. (2016). Effects of

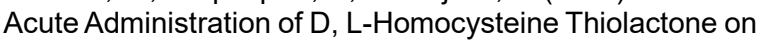
the Antioxidative Status of Rat. Intestine and Liver Acta Veterinaria, 66(1), 26-36. doi: 10.1515/acve-2016-0002

[18] Sunnetcioglu, A., Alp, H. H., Sertogullarindan, B., Balaharoglu, R., \& Gunbatar, H. (2016). Evaluation of oxidative damage and antioxidant mechanisms in COPD, lung cancer, and obstructive sleep apnea syndrome. Resp Care, 61(2), 205-211. doi: 10.4187/respcare.04209

[19] Tastekin, D., Erturk, K., Bozbey, H. U., Olmuscelik, O., Kizitan, H., Tuna, S., \& Tas, F. (2015). Plasma homocysteine, folate and vitamin B12 levels in patients with lung cancer. Exp Oncol, 37(3), 218-222.

[20] Tseimakh, I. Ya., Momot, A. P., Kostiuchenko, G. I., Mamaev, A. N., Filonova, Yu. A., Kornilova, T. A., ... \& Chuchalin, A. G. (2013). The role of endothelial dysfunction, conjugation of hemostatic and systemic inflammatory reactions in the pathogenesis of exacerbation of chronic obstructive pulmonary disease, dependent on infectious inflammation. Therapeutic archive, 85(3), 17-22.

[21] Yang, J., Li, H., Deng, H., \& Wang, Z. (2018). Association of One-Carbon Metabolism-Related Vitamins (Folate, B6, B12), Homocysteine and Methionine With the Risk of Lung Cancer: Systematic Review and Meta-Analysis. Front Oncol, (8), 493. doi: 10.3389/fonc.2018.00493

[22] Zaichko, N. V., Lutsiuk, M. B., \& Hryhorieva, G. O. (2012), Hyperhomocysteinemia: medical, social and pharmacological aspects. Pharmaceutical courier, (9), 30-35.

[23] Zobova, D. A., \& Kozlov, S. A. (2016). The role of homocysteine in the pathogenesis of certain diseases. Medical Sciences, 39(3), 132-144. doi: 10.21685/2072-3032-2016-3-15

\section{ОСОБЛИВОСТІ ГІСТОЛОГІЧНИХ ЗМІН ЛЕГЕНЬ ТВАРИН ЗРІЛОГО ВІКУ ЗА УМОВ ГІПЕРГОМОЦИСТЕЇНЕМІЇ}

Самборська І. А., Маєвський О. Є., Небесна 3. М.

Гіпергомоцистеїнемія $\epsilon$ загальновизнаним фактором ризику розвитку атеросклерозу, ішемічної хвороби серия, інсульту, венозних тромбозів. Однак за останні десятиліття спектр захворювань, асоційованих з підвищеним рівнем гомоцистеїну, значно розширився. Наразі активно вивчається вплив даної амінокислоти на виникнення та розвиток патологій органів дихальної системи, зокрема, хронічного обструктивного захворювання легень, бронхіальної астми, раку легень та плеври. Метою дослідження $є$ вивчення особливостей гістологічних змін легень шурів зрілого віку за умов гіпергомоцистеїнемії. Експериментальне дослідження проведене на 22 білих нелінійних статевозрілих (6-8 місяців) щурах-самцях. В ході експерименту тварин поділено на дві групи - контрольну і дослідну. Моделювання стану стійкої гіпергомоцистеїнемії досягали шляхом введення щурам дослідної групи тіолактону гомоцистеїну в дозі 200 мг/кг маси тіла інтрагастрально протягом 60 днів. Гістологічні препарати вивчали за допомогою світлового мікроскопа SEO SCAN та фотодокументували за допомогою відеокамери Vision CCD Camera з системою виводу зображення з гістологічних препаратів. Проведені гістологічні дослідження легень тварин зрілого віку за умов гіпергомоцистеїнемії встановили пристосувально-компенсаторні та деструктивні зміни компонентів органу. Виявлені дисциркуляторні розлади, ремоделювання стінки бронхів із формуванням у них запальних інфрільтратів. В респіраторному відділі легень виявлено значні площі дис- та ателектазів, та емфрізематозно змінені ділянки паренхіми. В альвеолярних перегородках, перибронхіально та паравазально визначено гісто- та лейкоцитарну інфрільтрацію, формування запальних конгломератів. Ремоделювання стінок судин, особливо мікроциркуляторного русла, призводить до порушення кровопостачання органу та гіпоперфузії тканини легень.

Ключові слова: гіпергомоцистеїнемія, ремоделювання судин, ендотеліальна дисфункція, дисциркуляторні розлади.

\section{ОСОБЕННОСТИ ГИСТОЛОГИЧЕСКИХ ИЗМЕНЕНИЙ ЛЕГКИХ ЖИВОТНЫХ ЗРЕЛОГО ВОЗРАСТА В УСЛОВИЯХ ГИПЕРГОМОЦИСТЕИНЕМИИ \\ Самборская И. А., Маевский А. Е., Небесная 3. М.}

Гипергомоцистеинемия является общепризнанным фрактором риска развития атеросклероза, ишемической болезни сердца, инсульта, венозных тромбозов. Однако за последние десятилетия спектр заболеваний, ассоциированных с повышенным уровнем гомоцистеина, значительно расширился. Сейчас активно изучается влияние данной аминокислоты на возникновение и развитие патологий органов дыхательной системы, в частности, хронического обструктивного заболевания легких, бронхиальной астмы, рака легких и плевры. Целью исследования является изучение особенностей гистологических изменений легких крыс зрелого возраста в условиях гипергомоцистеинемии. Экспериментальное исследование проведено на 22 белых нелинейных половозрелых (6-8 месяцев) крысах-самцах. В ходе эксперимента животных разделили на две группы - контрольную и опытную. Моделирование состояния устойчивой гипергомоцистеинемии достигали путем введения крысам опытной группы гомоцистеин тиолактона в дозе 200 мг/ка массы тела интрагастрально в течении 60 дней. Гистологические препараты изучали с помощью светового микроскопа SEO SCAN и фотодокументировали с помощью видеокамеры Vision CCD Camera c системой вывода изображения с гистологических препаратов. Проведенные гистологические исследования легких животных зрелого возраста в условиях гипергомоцистеинемии установили приспособительные-компенсаторные и деструктивные изменения компонентов органа. Выявлены дисциркуляторные расстройства, ремоделирование стенки бронхов с формированием в них воспалительных инфильтратов. В респираторном 
отделе легких выявлены значительные площади дис- и ателектазов, и эмфизематозно измененные участки паренхимы. $B$ альвеолярных перегородках, перибронхиально и паравазально определено гисто- и лейкоцитарную инфильтрацию, формирование воспалительных конгломератов. Ремоделирование стенок сосудов, особенно микроциркуляторного русла, приводит к нарушению кровоснабжения органа и гипоперфузии ткани легких.

Ключевые слова: гипергомоцистеинемия, ремоделирование сосудов, эндотелиальная дисфункция, дисциркуляторные расстройства. 